\title{
Editorial
}

\section{Is there a way?}

I am currently a member of a working party set up in my own university to look into a range of IT matters, including learning technology, with the aim of producing a mediumterm institutional plan. At many of the meetings I attend, I hear about the urgency of focusing our CAL effort, but the conviction around the table is often tempered by lecturers' complaints that the off-the-shelf courseware they have tried either does not work well, or does not fit their particular needs, or both. So a suggestion is made: we should move in the direction of developing our own high-quality educational software tailored to our individual requirements. And since these requirements are very diverse over the whole campus, we should establish a Centre for Educational Technology, a Courseware Resources and Advice Unit, a Virtual Learning Development Laboratory, an Institute for Computer-Based Academic Practice . . . call it what you will. It should be staffed by experts who can advise departments and produce for them, or help them to produce, the exact software they require. It should be supported by a battalion of technicians, and should not only be equipped with white-hot multimedia but also backed by sufficient financial resources to ensure continuous upgrades so as to remain in a permanent state of state-of-the-art. The bank balance is not as healthy as it might be (whose is?), but the university management must nevertheless somehow be convinced of the necessity of spending money on the project.

I wonder how many ALT members recognize the scenario. I know some who certainly will be familiar with at least parts of it. Most HE institutions utter noises about the need to make as much use as possible of computer technology in teaching, but in a significant number of them the decision-makers are still unwilling to commit money while they are being given contradictory messages. They are informed on the one hand that the future success of the institution may depend on a large-scale implementation of learning 
technology, and on the other that comparatively little educational software is being used within curricula because what is available is so often defective or otherwise unsuitable. In their minds, the two arguments do not converge on an expensive, wide-ranging programme of courseware development.

Part of the thinking behind the TLTP initiative was that it would address this problem: that is, that it would bring together expertise, thus avoiding duplication of effort, and that the targeted software produced would be made available to appropriate departments in institutions nation-wide. But TLTP has had less success than was hoped for in seeing the resulting products actually used, let alone relied upon as indispensable teaching resources. I do not believe that this situation is primarily due to a xenophobic not-invented-here syndrome, but rather to the fact that most TLTP products genuinely fail to measure up precisely to course requirements and standards, for whatever reasons.

I have dealt with essentially the same issue from a different angle in an editorial in this journal more than three years ago, and am no further on than I was then in being able to propose a practicable solution to what is, for ALT, a major strategic problem. By the time this editorial appears, we shall have had ALT-C 96, where we shall doubtless have heard paper after paper enthusing directly or indirectly about the benefits of learning technology. But the authors of those papers will be preaching to the converted and the ready-to-be-converted. What should we do to convince Doubting Thomas?

\section{Gabriel Jacobs}

